\title{
TOPOLÓGIAI MÓDSZEREK ALKALMAZÁSA
}

\author{
Szabó Kristóf \\ PhD hallgató, Miskolci Egyetem \\ Szerszámgépészeti és Mechatronikai Intézet, Szerszámgépek Intézeti Tanszéke \\ 3515 Miskolc, Miskolc-Egyetemváros, e-mail: szabo.kristof@uni-miskolc.hu
}

\begin{abstract}
Absztrakt
Az alábbi cikk röviden összefoglalja a napjainkban alkalmazható tervezést segitö módszereket, mint például az integrált CAD rendszerekben elterjedö topológiai optimalizációt és a generativ tervezést. Az emlitett módszerek nyújtotta eredményeket egy esettanulmány segitségével mutatjuk be és hasonlitjuk össze.
\end{abstract}

Kulcsszavak: géptervezés, tervezésmódszertan, generativ tervezés, topológiai optimalizálás

\begin{abstract}
The following article briefly summarizes the design aids currently in use, such as topology optimization and generative design, which are common in integrated CAD systems. The results provided by these methods are presented and compared with the help of a case study.
\end{abstract}

Keywords: machine design, design theory, generative design, topology optimisation

\section{Bevezetés}

Gépek és szerkezetek létrehozásakor a tervezési feladatot különböző módszerekkel lehet elvégezni. Ezen metódusok közé sorolhatók az elmúlt évszázadban kialakult és folyamatos fejlődésen áteső tervezésmódszertani ismeretek és lépések. Géptervezés szempontjából meghatározó szerepet töltenek be a Miskolci Egyetemhez kapcsolódó különféle eljárások és technikák [1], [5]-[7]. Minden tervezési módszernek vannak előnyei és hátrányai, de a legmegfelelőbb módszert a tervezői gárda képzettsége és az adott feladat típusa határozza meg. A folyamatot nagymértékben befolyásolja annak eszközigénye, de törekedni kell a jelen kor technikai és technológiai szintjét fenntartani és legjobb tudás szerint kihasználni. Megfigyelhető, hogy az ipar számos területén az emberi munka aránya csökken, a gépek és egyéb gyártóeszközök munkájához képest. Ez a fejlődési folyamat velejárója, amely reményében gyorsabban, pontosabban és adott esetben kevesebb költség mellett adhatunk megoldást egy adott feladatra, igényre. Kedvező felállásnak tünik az a rendszer, ahol az ember csupán információt közöl és döntéseket hoz, miközben a berendezés dolgozik. A terméktervezés területén is hasonló folyamatok mennek végbe, köszönhetően az integrált CAD rendszerekben elterjedő generatív tervezési modulnak, amely például szolgál az előzők során említett filozófiának. A tervezőmérnöki tevékenység a megfelelö információ pontos megadására és a kapott eredmények közti kiválasztásra korlátozódik.

\section{Az alkatrész bemutatása}

Az esettanulmány egy egyszerü geometriai elemekből felépülő alkatrész megtervezését fogja bemutatni, felhasználva a jelen kor nyújtotta tervezési módszereket, mint például a generatív tervezést. A kiin- 
duló alkatrész egy függesztő konzol, amit egy adott síkra csavarkötéssel rögzítünk. Az alkatrészen elhelyezkedő furatba teher akasztható, így a konzol húzó igénybevételt szenved.
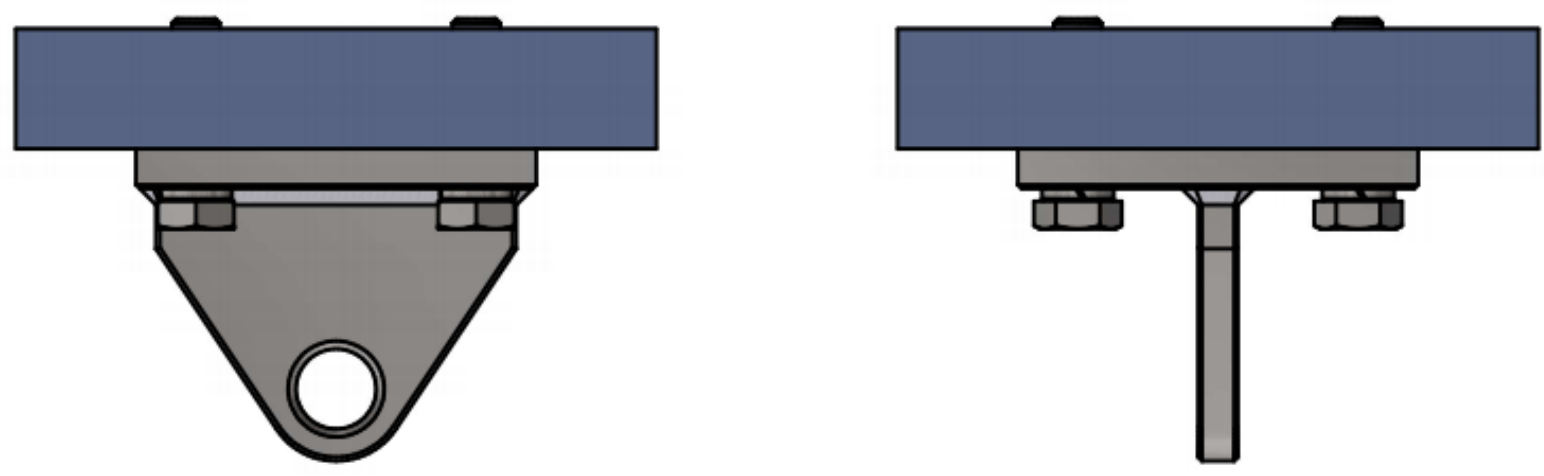

1. ábra. A vizsgált alkatrész beépitett állapota.

A képen jól látható, hogy az alkatrészt négy darab M12-es csavarral rögzítjük a vízszintes síkhoz. A vizsgálat során azt feltételezzük, hogy az alkalmazott csavarkötés megfelelő a kialakuló feszültségi állapotok elviselésére. Az alkatrész alján található furatba rögzítő kampót vagy csapot illeszthetünk. A konzol két $10[\mathrm{~mm}]$ vastagságú lemezből áll, amiket hegesztett kötéssel egyesítünk. A modell alkotáskor a hegesztett kötés hatását elhanyagoljuk.

1. táblázat. Az alkatrész anyagának jellemzői

\begin{tabular}{|l|c|}
\multicolumn{2}{c}{ Anyagjellemzők } \\
\hline Elnevezés & rozsdamentes acél 1.4125(440C) \\
\hline Folyáshatár & $689[\mathrm{MPa}]$ \\
\hline Szakítószilárdság & $861,25[\mathrm{MPa}]$ \\
\hline Young modulus & $206,7[\mathrm{GPa}]$ \\
\hline Poisson tényező & 0,27 \\
\hline Nyírási modulus & $83900[\mathrm{MPa}]$ \\
\hline Sürüség & $7,75\left[\mathrm{~g} / \mathrm{cm}^{3}\right]$
\end{tabular}

Az eredmények összehasonlíthatóságának érdekében a kezdeti munkadarabon egy előzetes végeselemes szimulációt végzünk, így ismertté válik az alkatrész teherbírása. A végeselemes analízishez az Autodesk Inventor programot használtuk. A vizsgálat során a terhelés hatására ébredő maximális feszültség és maximális elmozdulás értékét keressük. 


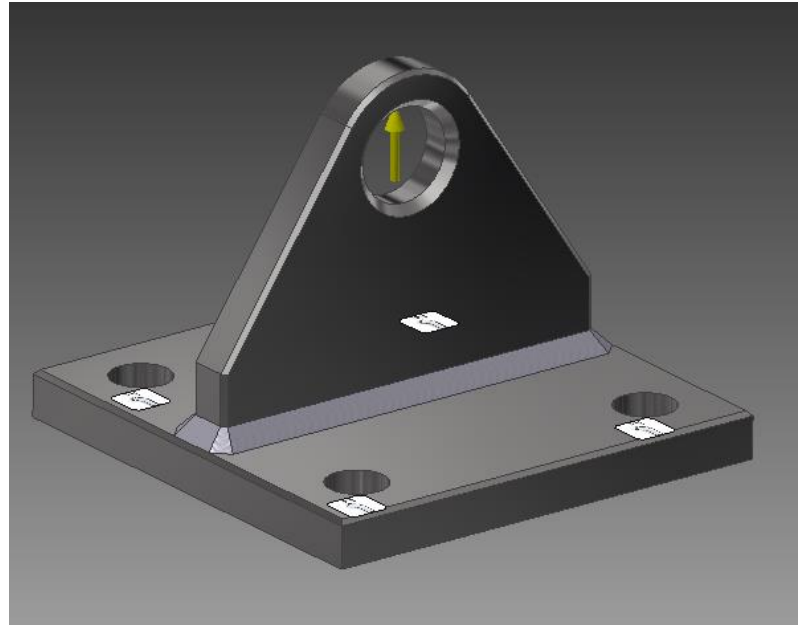

2. ábra. A terhelöerö és a rögzitési pontok elhelyezése.

Az alkatrészen felvett terhelőerő támadási pontját és irányát a 2. ábrán látható sárga nyíl mutatja. Az alkatrészgeometria szempontjából a megadott terhelés iránya kritikusnak számít. A terhelés statikusnak tekinthető, amelynek nagysága $50[\mathrm{kN}]$. Az alkatrész előkészítése a rögzítési pontok meghatározásával folytatódik, amelyeket a furatok középpontjan definiálunk, ezeket az ábrán látható fehér lakatok szimbolizálják.
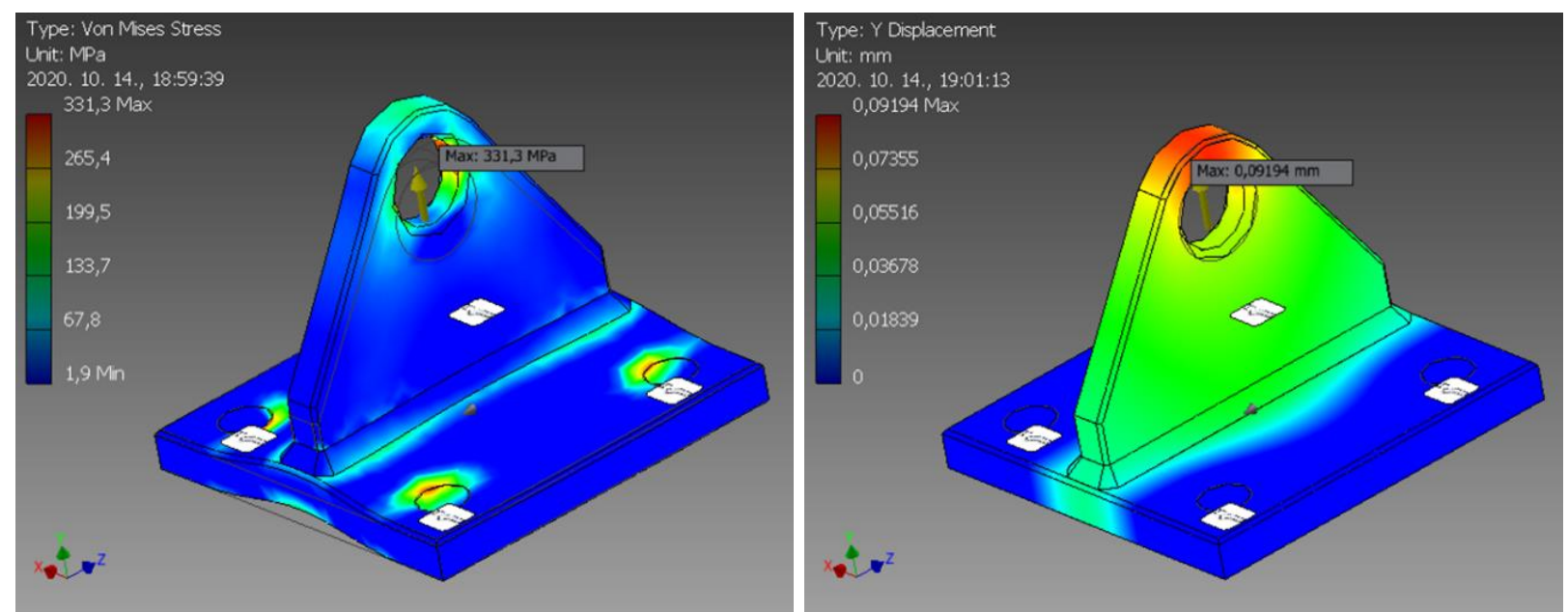

3. ábra. Az eredeti alkatrészen kialakuló feszültségi-és alakváltozási állapot.

A vizsgálat eredményei alapján a terhelőerő hatására a referencia modellen mérhető legnagyobb feszültség 331,3 [MPa] és a legnagyobb elmozdulás 0,091 [mm].

\section{Topológiai optimalizáció alkalmazása}

A topológiai optimalizáláshoz egy előzetes testmodell szükséges, amelyet a jelenlegi tanulmányban a referencia alkatrész módosított geometriája biztosít [8]-[11]. 


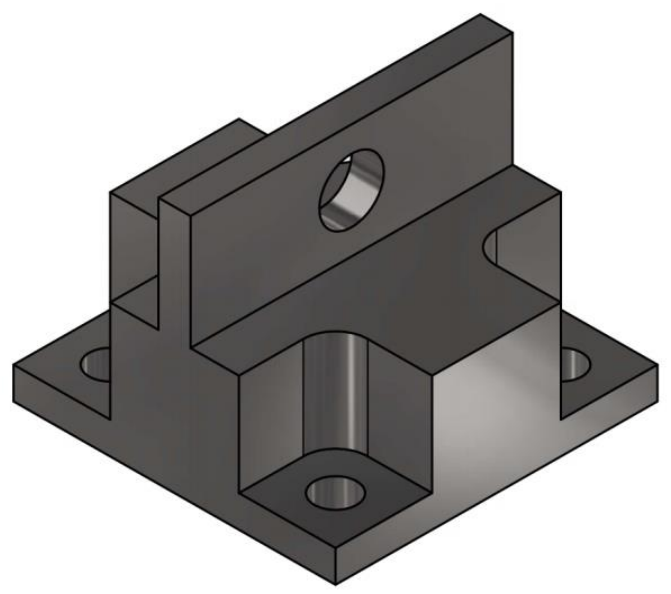

4. ábra. A referencia alkatrész módositott modellje.

A módosítások növelték az eredeti modell térfogatát, ügyelve arra, hogy a funkciók ellátását ne akadályozza és a szerelési feladatok megfelelően elláthatók legyenek. A mủvelet során kiválasztott anyag megegyezik az eddig alkalmazott rozsdamentes acél 1.4125(440C)-vel. Hasonló módon felvettük az $50[\mathrm{kN}]$ nagyságú terhelőerőt, amelynek iránya változatlan. A továbbiakban meghatároztuk a rögzítési pontokat, amelyek megegyeznek a korábban alkalmazottakkal. Az egyes furatok miatt szükséges úgynevezett fix térfogatok definiálása, amelyek az optimalizálás során tömör testek maradnak [2], [4]. Az összehasonlítható eredmények érdekében gondolni kell arra, hogy a topológiai optimalizáció és a generatív tervezés során ugyanolyan paraméterekkel rendelkező fix térfogatokat adjunk meg. Ez lényegében azt jelenti, hogy minden furatnál egy-egy forgástestet definiálunk úgy, hogy a 13 [mm] átmérojjü furatoknál 20 [mm] átmérőjü hengereket, a 20 [mm] átmérőjü furatnál pedig 36 [mm] átméröjü hengert rögzítettünk. Ezen megoldásokat a program zöld színü testekkel szemlélteti. A szoftver lehetöséget ad szimmetriasík megadására vagy minimális hálózási beállításokra, ezek megfelelő megválasztása csökkentheti a számolási időt.
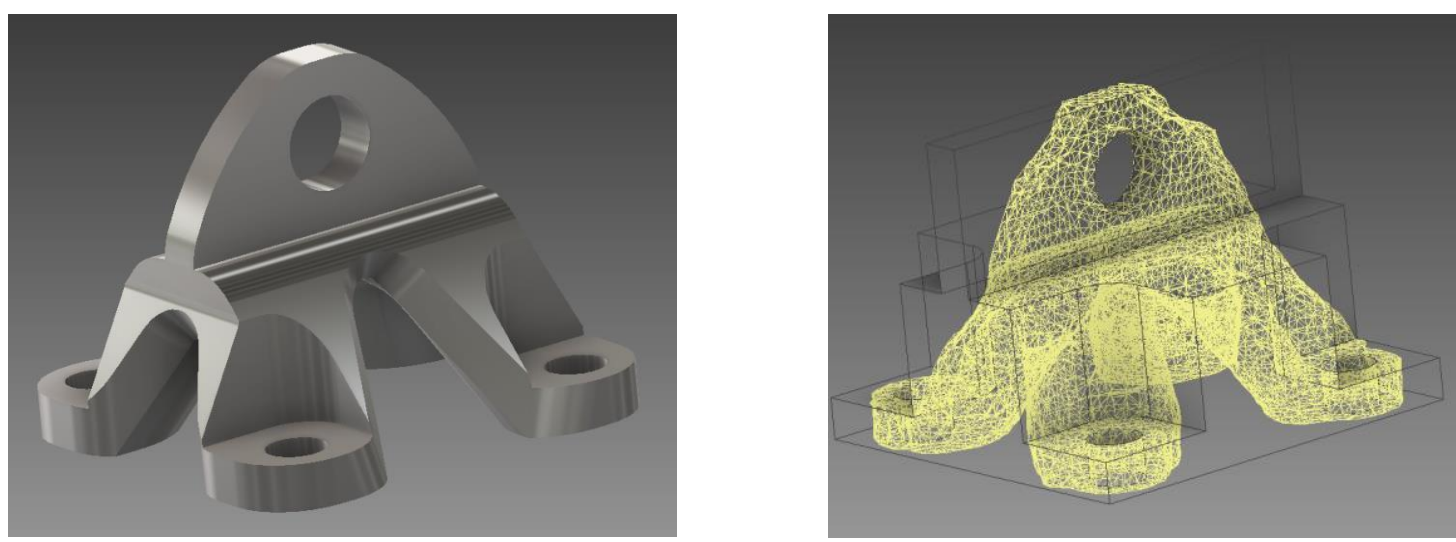

5. ábra. A topológiai optimalizáció eredménye.

Az 5. ábrán láthatók az optimalizálási folyamat eredményei. A tervezés folyamán a tömegcsökkentést állítottunk optimalizálási célnak, amelynek értéke százalékos mértékben adható meg. A kapott eredmények az eredeti modellhez képest $13 \%$-os tömegcsökkentés beállítása mellett adódtak, ennek meg- 
felelően az alkatrész tömege $0,91[\mathrm{~kg}]$. A hálózott modellen látható, hogy a felület nagyon egyenetlen. A forgácsolással való megmunkálás érdekében az egyes tartományok síkokkal lettek közelítve. Az egyik legfontosabb szempont, hogy a kialakult geometria megfelel-e a kívánt terhelések elviselésére. A továbbiakban az adott kérdésre végeselemes szimuláció segítségével keressük a választ.
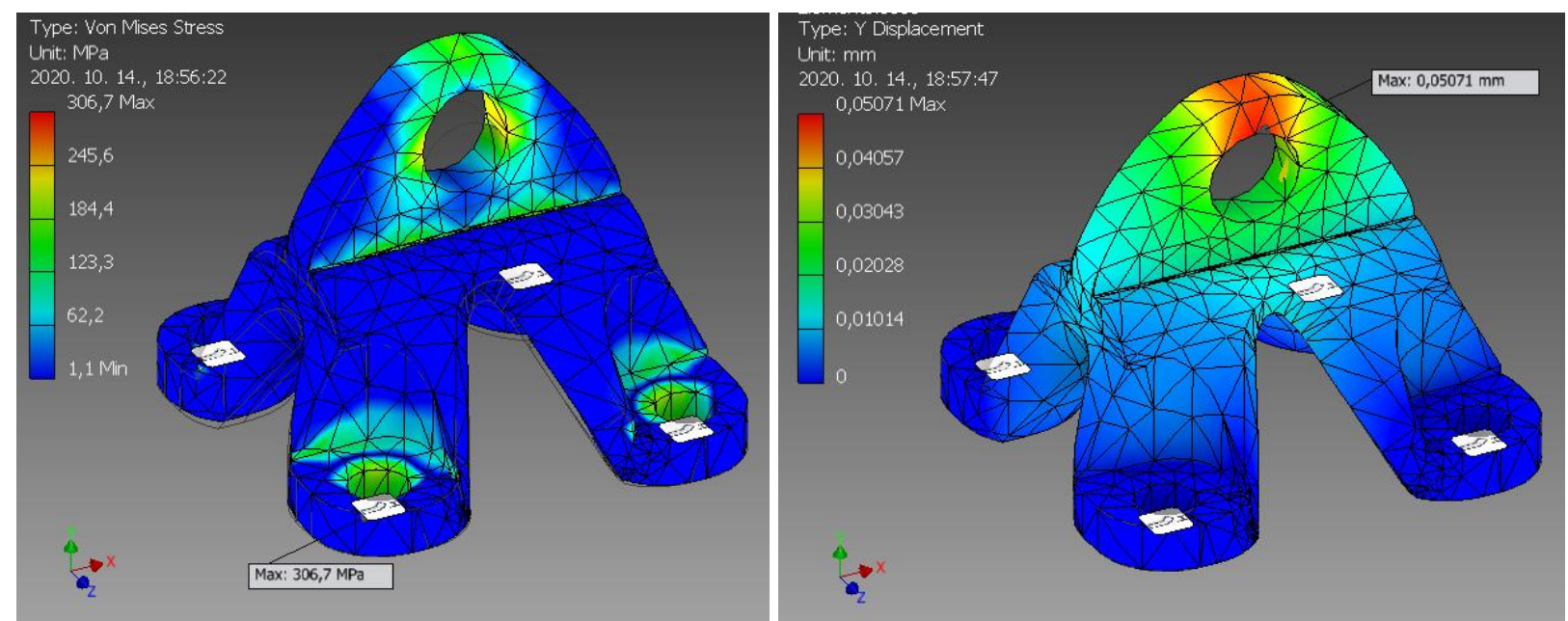

6. ábra. Az optimált alkatrészen kialakuló feszültségi- és alakváltozási állapot.

A 6. ábrán látható, hogy a terhelés hatására kialakult maximális feszültség mértéke 306,7 [MPa], amely az alkalmazott biztonsági tényező mellett megfelelő. A deformáció maximális értéke 0,05 $[\mathrm{mm}]$.

\section{Az alkatrész generatív tervezéssel való előállítása}

A cikk további pontjában bemutatjuk a generatív tervezési módszerrel előállított alkatrész konstruálásának menetét és a kapott eredmények értékelését. A folyamathoz szükséges elökészületek, mint például a tervezési, nem tervezési és fix térfogatok modellezése és felvétele Autodesk Inventor programban készültek, majd a generatív tervező modul az Autodesk Fusion 360 programban került alkalmazásra. Lényegében hasonló folyamaton kell végig haladni, mint a topológiai optimalizáció esetén. Az egyes beállítások teljes mértékben megfelelnek a korábban használtakkal, tehát a tervezést korlátozó geometria, a használni kívánt anyag, a kényszerezettség és a terhelőerő nagysága és iránya megegyezik a korábban definiált paraméterekkel. Miután a megfelelő értékek beállításra kerültek következő lépésben egy ellenőrző funkció indítása szükséges. A feladata, hogy végigfut a beállításokon és ha valamilyen hiányosságot vagy ellentmondást észlel, akkor jelzi azt a program kezelőjének [3]. Amenynyiben általunk bevitt anyagnak nincs minden tulajdonsága megfelelően definiálva, vagy kiválasztott megmunkáláshoz nem választottunk megfelelő anyagot, akkor a szoftver értesíti a felhasználót. Célszerü egy előnézeti parancsot futtatni, amely segítségével bonyolultabb alkatrészek esetén ellenőrizhető a tervezési térfogatok helyes megválasztása. Ezen ellenőrző funkciók után indítható a tervezési folyamat, amely teljes egészében egy felhő alapú tárhelyen történik. Ennek megfelelően az indítás után a számítógép akár ki is kapcsolható. 


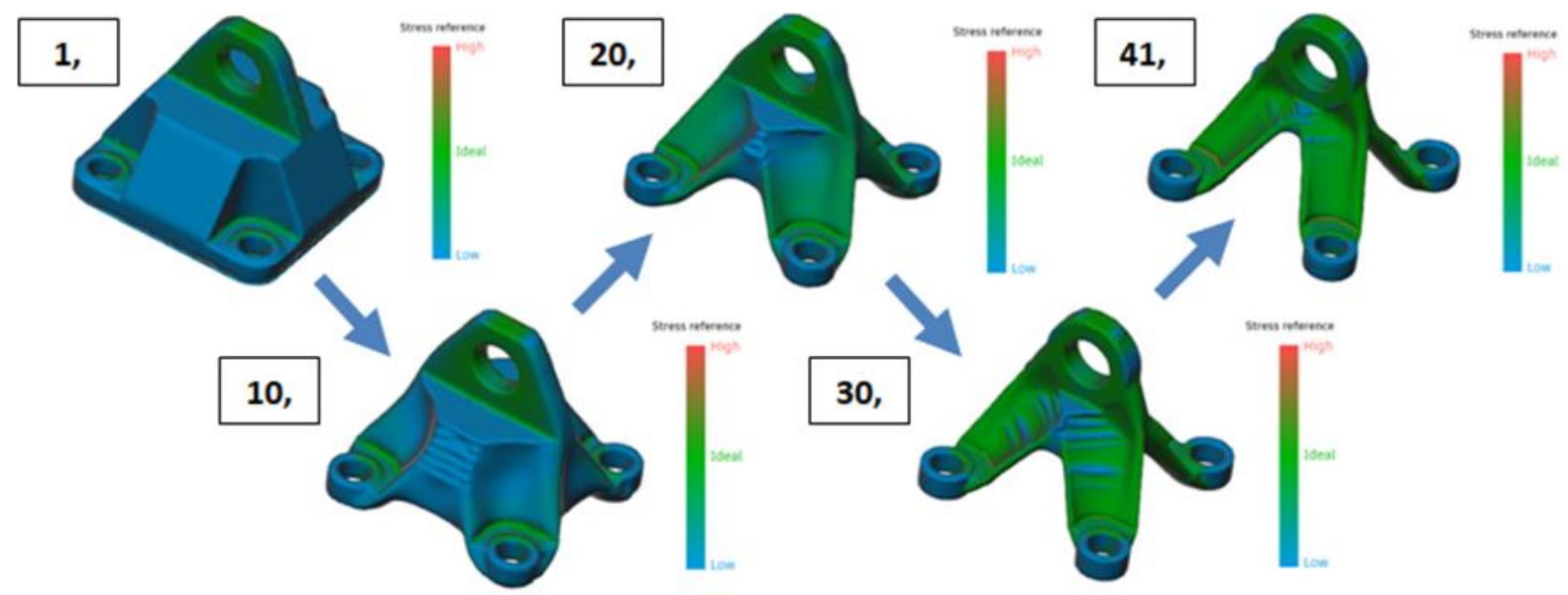

7. ábra. A generálási folyamat iterációs lépései.

Célszerủ megemlíteni, hogy számos anyag és gyártástechnológia kiválasztása lehetséges, ezért a megoldások száma meglehetősen sok. A különféle megoldásokat célszerü minél hamarabb szürni. Ha egy adott irányban elindul a megoldások generálása, akkor azt egy alkatrészként kezelendő, tehát megnyitás után azon a logikai szálon történő iterációk eredménye is megtekinthető és lehetséges megoldásként kezelendő. Előfordulhat, hogy számunkra kedvező a megoldás generálás iránya, de a végeredmény nem teljesen felel meg az elvárásoknak, akkor felhasználható a folyamat köztes eleme. Az alábbi ábrán látható az iteráción áteső alkatrészek fejlődése. Lehetőség van a feszültségi állapot monitorozására, amely segítségével további vizsgálat nélkül kapunk információt az adott iterációs eredmények mechanikai tulajdonságáról.
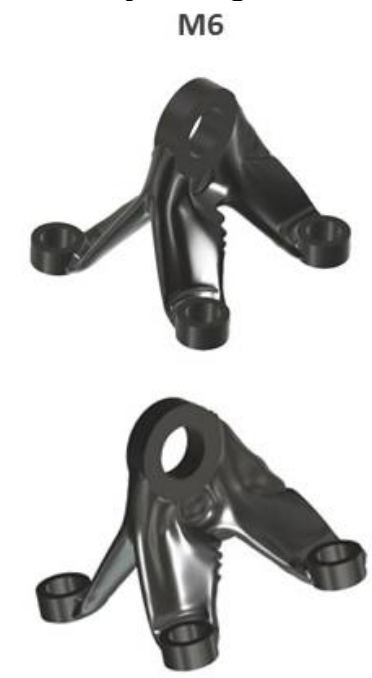

M9
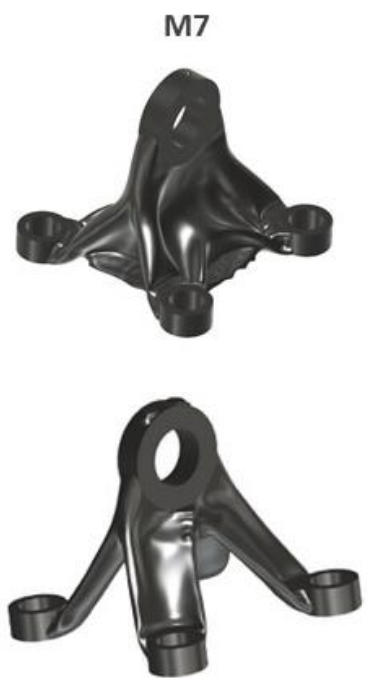

M10
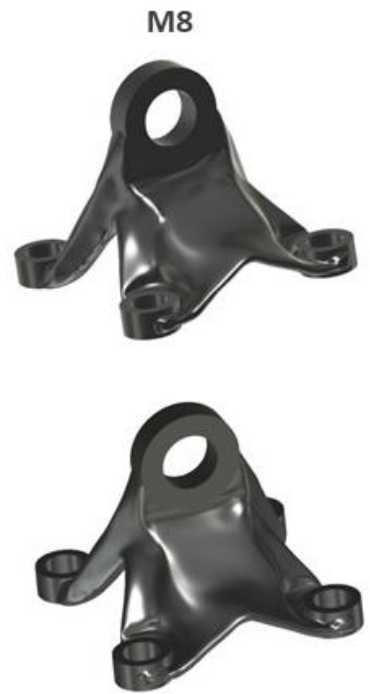

M11

8. ábra. A generatív tervezési folyamat eredményei.

A generálás lefutása hat alkatrészt eredményezett, amely alatt kettőszázharminc iterációs lépést képezett le a szoftver, melyek egytől egyig teljes értékủ alkatrészek. Következő lépésben kiválasztottuk a 
legmegfelelőbb változatot. A program rendelkezik beépített összehasonlító funkcióval, amelyben különböző feltételeket lehet hozzárendelni az egyes koordináta tengelyekhez és a program kiértékeli az egyes megoldásokat.

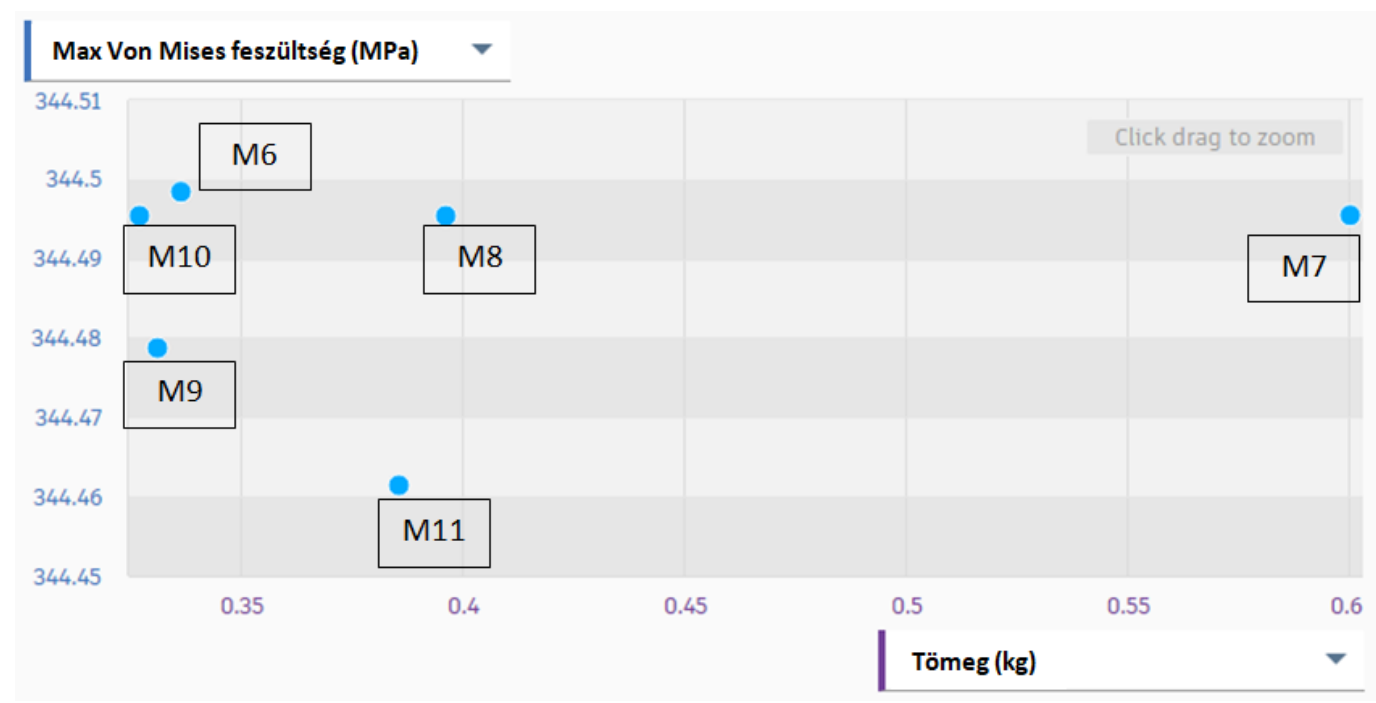

9. ábra. Osztályozás a feszültségi állapot és a tömeg alapján.

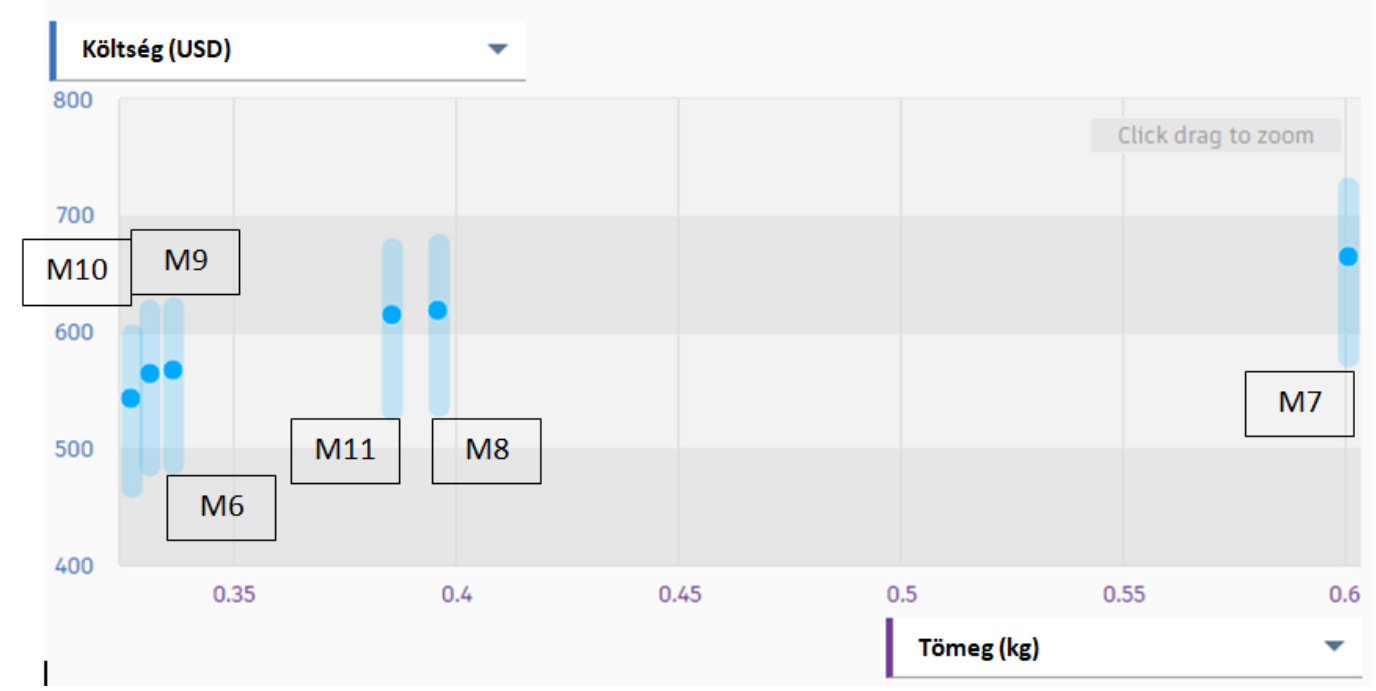

10. ábra. Osztályozás a gyártási költéség és a tömeg alapján. 


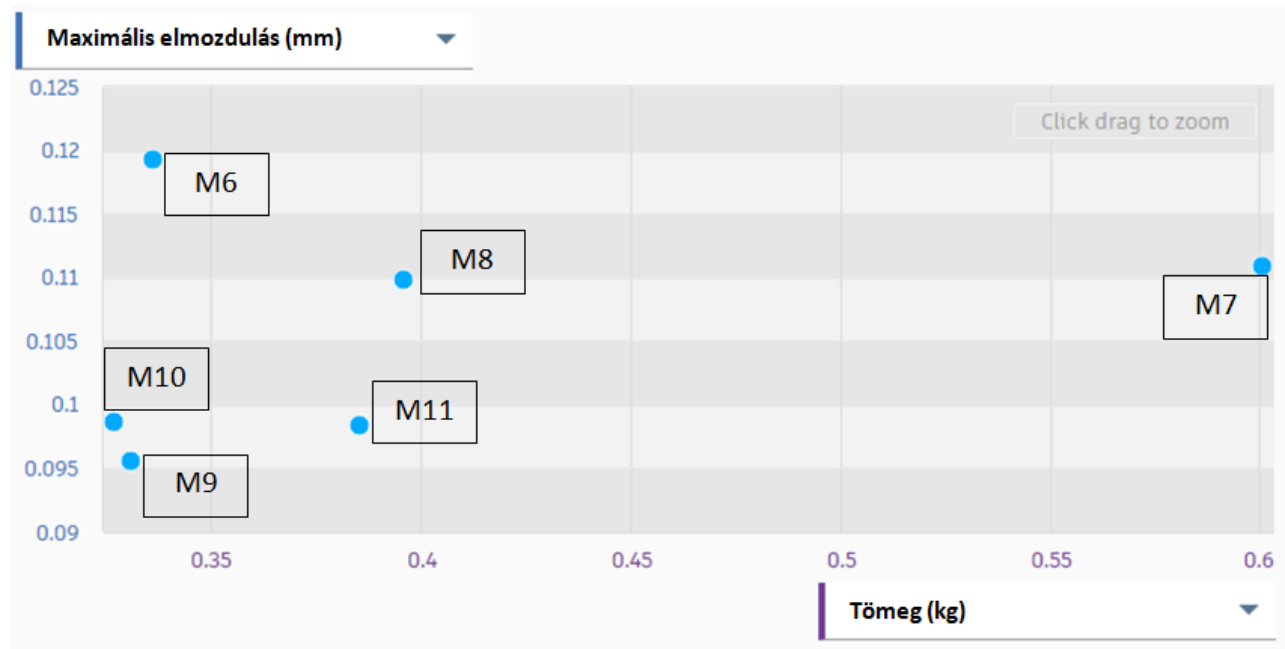

11. ábra. Osztályozás a deformáció és a tömeg alapján.

Az értékelési alapján az $M 9$ és $M 10$ megoldás hasonlóan előnyös konstrukciónak bizonyult. A maximális elmozdulások alapján minimális különbséget mutatnak, de az $M 10$ sorszámú megoldás tömege és gyártási költsége alacsonyabb. Ennek megfelelően a generatív módszer segítségével elöállított alkatrész esetében a kiválasztott konstrukció az M10 sorszámúra esett. A tanulmány során kapott eredmények alapján a 2. táblázat összefoglalja az egyes módszerekkel megalkotott alkatrészek tulajdonságait.

2. táblázat. A vizsgálat eredményeinek összesitése

\begin{tabular}{|l|c|c|c|}
\hline \multicolumn{1}{|c}{$\begin{array}{c}\text { Hagyományos } \\
\text { tervezés }\end{array}$} & $\begin{array}{c}\text { Topológiai } \\
\text { optimalizáció }\end{array}$ & $\begin{array}{c}\text { Generatív } \\
\text { tervezés }\end{array}$ \\
\hline Darabszám & Nagysorozat & Kissorozat & Egyedi \\
\hline Változatok & $1[\mathrm{db}]$ & $1[\mathrm{db}]$ & $230[\mathrm{db}]$ \\
\hline Megmunkálás & Vágás és hegesztés & Marás & Additív gyártás \\
\hline Szilárdság & $331[\mathrm{MPa}]$ & $306[\mathrm{MPa}]$ & $344[\mathrm{MPa}]$ \\
\hline Deformáció & $0,09[\mathrm{~mm}]$ & $0,05[\mathrm{~mm}]$ & $0,09[\mathrm{~mm}]$ \\
\hline Biztonsági elö́rás & Megfelel & Megfelel & Megfelel \\
\hline Méret & Megfelel & Megfelel & Megfelel \\
\hline Tömeg & $1,07[\mathrm{~kg}]$ & $0,91[\mathrm{~kg}]$ & $0,32[\mathrm{~kg}]$ \\
\hline Tömegcsökkentés mérté- & $0 \%$ & $17 \%$ & $70 \%$ \\
\hline ke & Közepes & Nagy & Minimális \\
\hline Hulladék mennyisége & $10000 \mathrm{Ft}$ & $50000 \mathrm{Ft}$ & $200000 \mathrm{Ft}$ \\
\hline Költség
\end{tabular}

\section{5. Összefoglalás}

Az esettanulmány betekintést nyújt a jelenkori terméktervezés folyamatába és problémaköreibe. A cikk összehasonlítást végez három alkatrész tekintetében, amelyek eltérő módszerrel, eltérő szoftverben, de ugyan azon peremfeltételek megfelelésére szolgálnak. A klasszikus módszerrel tervezett alkat- 
rész megfelelö, ha a termék nagysorozatban állítandó elő és nem fontos a tömegcsökkentés. A topológiai optimalizálás felhasználásával tervezett alkatrész gyártása több tengelyes marógépen valósul meg, amely termelékenysége jelentősen kisebb a hagyományos tervezéshez képest. A gyártás közben keletkező hulladék mennyisége magas, ezért az ily módon tervezett alkatrész alkalmazása kis sorozatok esetén ajánlott, ahol a további előny a tömegcsökkentés. A generatív tervezési módszerrel tervezett alkatrész gyártása sok esetben csak additív technológiával kivitelezhetö, amely termelékenysége kicsi, de költsége magas. A gyártáshoz kapcsolódó pozitívum, hogy a hulladékképződés alacsony. Az alkatrész használata akkor ajánlott, ha fontos a tömegcsökkentés és a különleges vagy nehezen forgácsolható anyagok használata.

\section{Köszönetnyilvánítás}

A cikkben ismertetett kutató munka az EFOP-3.6.1-16-2016-00011 jelü „Fiatalodó és Megújuló Egyetem - Innovatív Tudásváros - a Miskolci Egyetem intelligens szakosodást szolgáló intézményi fejlesztése" projekt részeként - a Széchenyi 2020 keretében - az Európai Unió támogatásával, az Európai Szociális Alap társfinanszírozásával valósul meg.

\section{Irodalom}

[1] Takács Gy., Zsiga Z., Szabóné Makó I., Hegedűs Gy. Gyártóeszközök módszeres tervezése, Nemzeti Tankönyvkiadó, (2011), Miskolc

[2] Szabó K., Hegedűs Gy.: A generativv tervezést támogató szoftverek rövid áttekintése, Multidiszciplináris Tudományok 2020, 10(3): 328-337. https://doi.org/10.35925/j.multi.2020.3.39

[3] Szabó K., Hegedűs Gy.: A generativ tervezés lépései integrált CAD rendszerekben, Multidiszciplináris Tudományok 2020, 10(4): 393-398. https://doi.org/10.35925/j.multi.2020.4.43

[4] Szabó K.; Hegedüs Gy.: Brief Overview of Generative Design Support Software, Design Of Machines and Structures 2020, 10(29: 123-132. https://doi.org/10.32972/dms.2020.023

[5] Hegedűs, Gy. A módszeres géptervezés alkalmazása ipari mérőgép fejlesztése estén, Doktoranduszok Fóruma 2002: Gépészmérnöki Kar szekciókiadványa. (2002)

[6] Kamondi, L., Sarka, F., Takács, Á. (2011). Fejlesztés- módszertani ismeretek, Nemzeti Tankönyvkiadó, Miskolc

[7] Pahl, G., Beitz, W., Feldhusen, J., Grote, K.H. (2007). Engineering Design - A Systematic Approach, London: Springer-Verlag, ISBN 978-1-84628-318-5

[8] Stejskal, T., Dovica, M., Svetlík, J., Demec, P., Hrivniak, L., Šašala, M. - Establishing the Optimal Density of the Michell Truss Members, Materials 2020, 13(17): 3867. https://doi.org/10.3390/ma13173867

[9] Zuo, K., Chen, L., Zhang, Y., Yang, J.: Study of key algorithms in topology optimization, The International Journal of Advanced Manufacturing Technology 2007, 32: 787-796. https://doi.org/10.1007/s00170-005-0387-0

[10] Gönczi, D.: Topológiai optimalizálási feladatok alapvető sajátosságai Abaqus végeselemes programrendszerben, Multidiszciplináris Tudományok 2021, 11(4): 177-187. https://doi.org/10.35925/j.multi.2021.4.22

[11] Trautmann, L.: Product customization and generative design, Multidiszciplináris Tudományok 2021, 11(4): 87-95. https://doi.org/10.35925/j.multi.2021.4.10 